\title{
First record of Polyonyx loimicola Sankolli, 1965 (Crustacea, Decapoda, Anomura, Porcellanidae) from the Red Sea, Egypt
}

\author{
Mohamed A. Amer ${ }^{1 *}$, Tohru Naruse ${ }^{2}$ and Masayuki Osawa ${ }^{3}$
}

\begin{abstract}
The first record of the porcellanid crab, Polyonyx loimicola Sankolli, 1965, from Ain-Sokhna, Suez Gulf, Egypt, the Red Sea, is provided far away from its known localities in India and Pakistan. The present specimens were found in association with one tube-dwelling polychaete species, Chaetopterus variopedatus (Renier, 1804), in soft sandy habitat. They agree well with the original description of $P$. loimicola in most of its diagnostic characters. Intraspecific variation is recognized in the number of ventral spines of the ambulatory propodi.
\end{abstract}

Keywords: Association habit, Indo-West Pacific, Porcellanidae, Red Sea, Tube-dwelling polychaete

\section{Introduction}

The porcellanid genus Polyonyx Stimpson, 1858 includes 32 species globally (Osawa and McLaughlin 2010; Osawa 2015, 2018; Osawa and Ng 2016; Osawa et al. 2018; Werding and Hiller 2019). Polyonyx species usually live in association with sponges and tube-dwelling polychaetes (Osawa and Chan 2010). Johnson (1958) divided the Indo-West Pacific species of the genus to three informal groups: $P$. biunguiculatus, $P$. denticulatus, and $P$. sinensis groups. Among the three groups, the $P$. denticulatus group was regarded as a different genus Aliaporcellana Nakasone and Miyake 1969. Moreover, Osawa (2015) suggested that the P. biunguiculatus group is very close to Aliaporcellana. The P. sinensis group now contains 18 species from the Indo-West Pacific (Osawa 2018; Werding and Hiller 2019) and is primary characterized by the carapace without spines on the lateral margins, the chela with various degrees of setation on the dorso-anterior surface and the dactyli of the ambulatory legs each with the dorsal claw much smaller than the ventral.

The Egyptian coasts represent the northern limits of the Red Sea, including the complete coasts of the Suez Gulf and the western coasts of the Aqaba Gulf, and have

\footnotetext{
*Correspondence: naseramer@azhar.edu.eg

${ }^{1}$ Zoology Department (Marine Biology Section), Faculty of Science, Al-Azhar University, Cairo 11884, Egypt

Full list of author information is available at the end of the article
}

a total length of about $1300 \mathrm{~km}$ (Head 1987). The Suez Gulf significantly differs from other areas of Egypt (western coasts of Aqaba Gulf and southern Egyptian coasts in the Red Sea) in geographical position, general environmental conditions and bathymetry. The Suez Gulf is considered to be the boundary between Africa and Asia, which extends from its south running from Ras Mohamed (Sinai Peninsula) and Westward at Gemsa Bay to the entrance of the Suez Canal (the northern limit), the coasts are represented by several habitats including sandy, rocky shores and coral reefs.

Despite the variety of the coasts and habitats, only three Polyonyx species have been reported from the Red Sea: P. biunguiculatus (Dana, 1852), P. pedalis Nobili, 1905, and P. triunguiculatus Zehntner, 1894 (Ramadan 1936; Barnard 1950; Lewinsohn 1969; Vine 1986; Osawa and Ng 2016). Vine (1986) listed four nomina of the " $P$. denticulatus group" from the Red Sea. However, as mentioned above, they are now placed in the genus Aliaporcellana: P. denticulatus Paul'son, 1875 and P. suluensis (Dana, 1852) are now considered conspecific and the current valid name is A. suluensis; P. pygmaeus (De Man, 1902) and P. pugilator Nobili, 1905 (incorrectly spelled as $P$. pugilatus by Vine 1986: 108) are also synonymous and the current valid name is A. pygmaea (Osawa and McLaughlin 2010). Werding and Hiller (2007) examined porcellanid collections from the Red

(c) The Author(s). 2019 Open Access This article is distributed under the terms of the Creative Commons Attribution 4.0 International License (http://creativecommons.org/licenses/by/4.0/), which permits unrestricted use, distribution, and reproduction in any medium, provided you give appropriate credit to the original author(s) and the source, provide a link to the Creative Commons license, and indicate if changes were made. The Creative Commons Public Domain Dedication waiver (http://creativecommons.org/publicdomain/zero/1.0/) applies to the data made available in this article, unless otherwise stated. 
Sea in some museums and listed 18 species including only one species of Polyonyx, P. triunguiculatus.

Porcellanid crabs from the Egyptian coasts have been reported only by a few studies (e.g., Nobili 1906; Lewinsohn 1969). Ramadan (1936) listed the decapod and stomatopod crustaceans from the Egyptian coasts, Red Sea, including seven porcellaniids: Pachycheles sculptus ( $\mathrm{H}$. Milne Edwards, 1834); Petrolisthes boscii (Audouin, 1826); P. leptocheles (Heller, 1861); P. ornatus (Paulson, 1875); P. rufescens (Heller, 1861); P. virgatus Paulson, 1875; and Porcellana inaequalis (Heller, 1861) now placed in the genus Pisidia Leach, 1820. Moreover, Werding and Hiller (2007) added six species to the Egyptian porcellanid fauna: Aliaporcellana suluensis (Dana, 1852); Pachycheles natalensis (Krauss, 1843); Petrolithes aegyptiacus Werding and Hiller, 2007; P. lamarckii (Leach, 1820); P. moluccensis (De Man, 1888) and Porcellanella haigae Sankarankutty, 1963 (based on a photograph taken by Lieske and Myers 2004, in a guide of Coral reefs of the Red Sea, Gulf of Aqaba), in addition to an unconfirmed species recorded as Petrolisthes cf. donanensis Osawa, 1997. Thus, at present 13 species in five genera of the Porcellanidae are recorded from the Egyptian Red Sea.

The present study reports Polyonyx loimicola Sankolli, 1965 , as an addition to the porcellanid fauna of the Red Sea and Egypt. This species was originally described from the western India and later recorded only from Pakistan (Siddiqui and Kazmi 2003).

\section{Materials and methods}

The specimens examined were collected from the northern part of the Suez Gulf (Ain-Sokhna), Red Sea, Egypt. They were obtained from tubes of chaetopterid worms found on soft sandy substratum in shallow intertidal region. The host species was identified in reference to Sun and Qiu (2014). The specimens are deposited in the Reference Collection and Museum of Zoology, Faculty of Science, Al-Azhar University, Egypt (RCAZUE.Crus.).

The morphological terminology follows those of Osawa and Chan (2010) and Osawa (2015). Measurements of the carapace and pereopods were made in accordance with Osawa et al. (2018). Abbreviations are as follows: CL, carapace length, and CW, carapace width.

\section{Results and discussion}

Porcellanidae Haworth, 1825

Polyonyx Stimpson, 1858

Polyonyx loimicola Sankolli, 1965

Polyonyx loimicola Sankolli, 1965: 285, pls. 1, 2.-Sankolli and Shenoy 1965: 316, unnumbered pl. figs. c, d.Tirmizi et al. 1989: 24.-Siddiqui and Kazmi 2003: 88 (list).

\section{Material examined}

RCAZUE.Crus. 36,401, 1 female (CL $4.7 \mathrm{~mm}$, CW 6.1 $\mathrm{mm})$, Ain-Sokhna, Suez Gulf, Red Sea, Egypt, 29 $50^{\prime}$ $43.8^{\prime \prime} \mathrm{N}, 32^{\circ} 30^{\prime} 0.5^{\prime \prime} \mathrm{E}$, coll. M. A. Amer, Feb. 2018. RCAZUE.Crus. 36,402, 1 male (CL $4.9 \mathrm{~mm}$, CW $5.7 \mathrm{~mm}$ ), same locality with RCAZUE.Crus. 36,401, using yabby pump, coll. M. A. Amer, Sep. 2018.

\section{Description}

Carapace (Figs. 1a, b, 2a) 1.2-1.3 times as wide as long, rectangular in general outline; branchial margins subparallel, slightly convergent posteriorly. Dorsal surface convex longitudinally, almost smooth, with few disconnected, fine transverse ridges on protogastric region; pair of mats of minute setae between rostrum and protogastric ridges; cervical grooves faint; metabranchial and adjacent regions with distinct long transverse ridges; two rounded, shallow depressions laterally in cardiac region. Branchial margins setose, denser in posterior region but sparser anteriorly. Rostrum directed somewhat downward, weakly trilobate; median lobe broadly triangular with rounded apex, barely visible in dorsal view; anterior margin with row of short setae.

Third thoracic sternite (Fig. 2b) trilobate; anterior margin with row of setae; median lobe broadly triangular, wider than lateral lobes. Fourth thoracic sternite smooth on surface, sloping anteriorly; anterior margin moderately concave medially.

Third maxilliped (Fig. 2c) ischium smooth, length about as long as maximum width; merus with well demarcated rounded lobe on ventrolateral (flexor) margin;

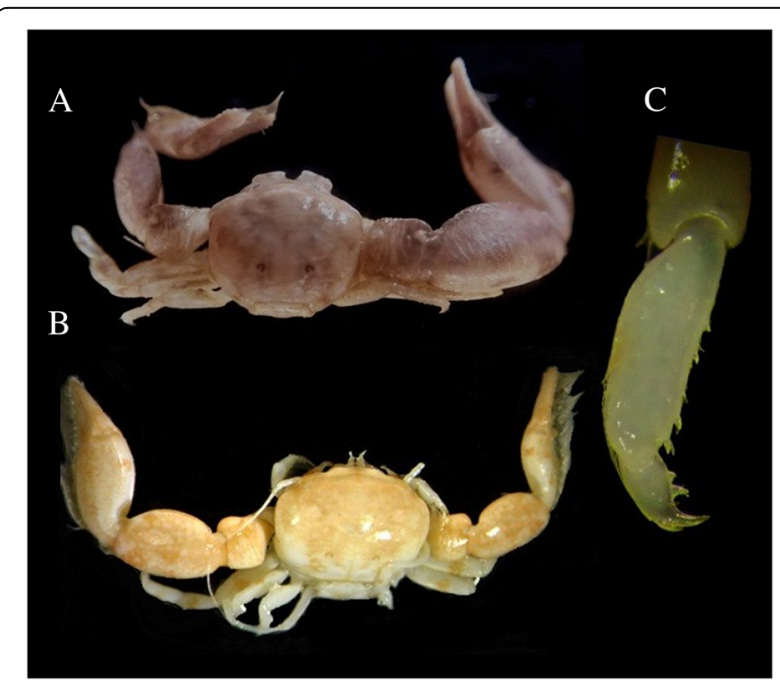

Fig. 1 Polyonyx loimicola Sankolli, 1965 from Suez Gulf, Red Sea, Egypt. a, b entire animal, dorsal view (a live coloration; b preserved coloration); c propodus and dactylus of third pereopod (second ambulatory leg), lateral view. a RCAZUE.Crus. 36,402, male, Cl 4.9 mm; b, c RCAZUE.Crus. 36,401, female, CL 4.7 mm 


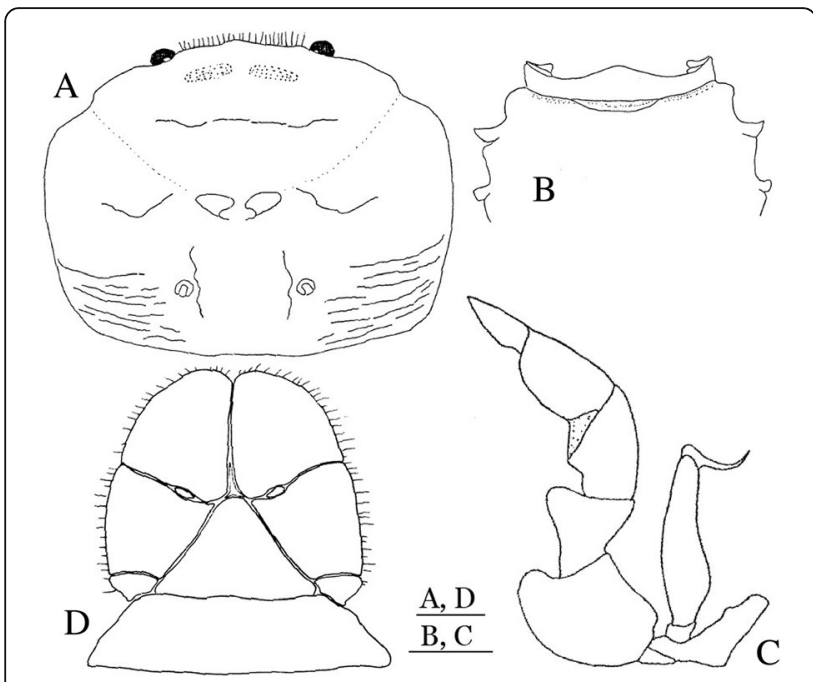

Fig. 2 Polyonyx loimicola Sankolli, 1965, from Suez Gulf, Red Sea, Egypt; RCAZUE.Crus. 36,401, female, CL $4.7 \mathrm{~mm}$. a carapace, dorsal view; $\mathbf{b}$ third and fourth thoracic sternites, ventral view; $\mathbf{c}$ left third maxilliped, lateral view; d telson, external view. Scales, a-c $=1 \mathrm{~mm}$, $\mathbf{d}=0.5 \mathrm{~mm}$. Setae not partially (a) or fully $(\mathbf{b}, \mathbf{c})$ drawn

propodus relatively short; carpus, propodus and dactylus with long setae on ventral (flexor) margins.

Chelipeds (Fig. 3a-d) unequal in size, larger in male than female. Larger cheliped with short to long setae on anterior, posterior and dorso-anterior margins in male,

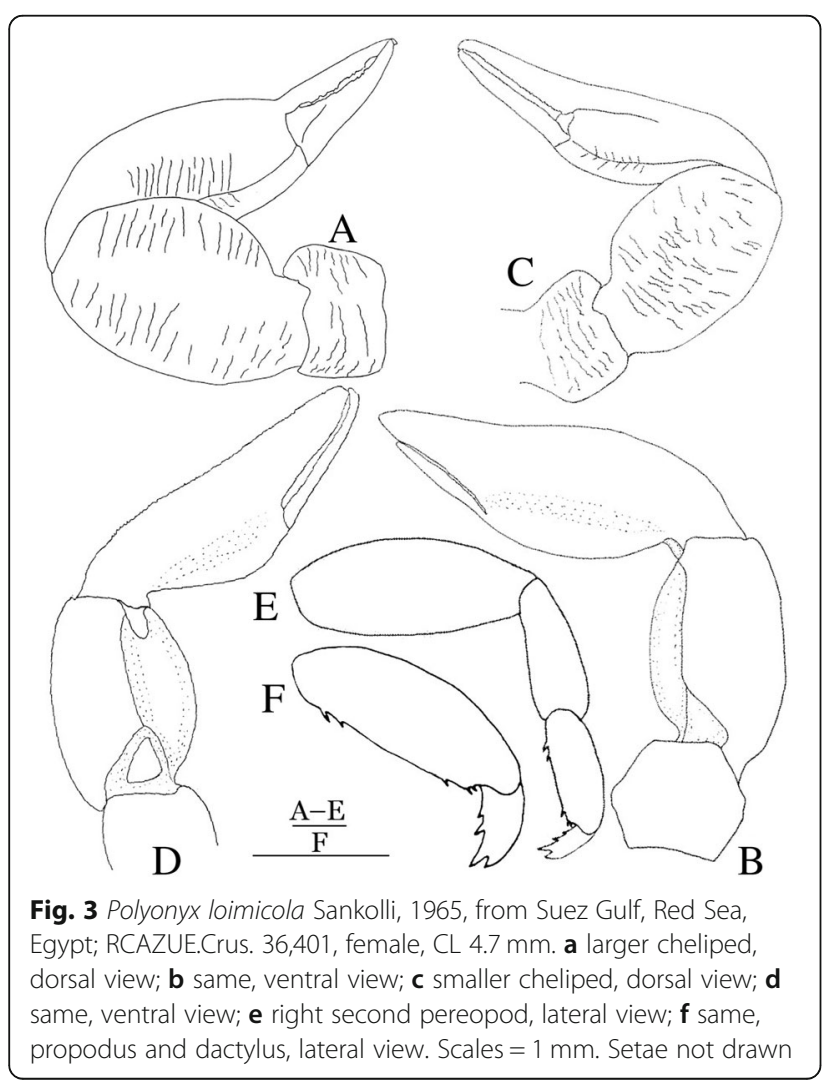

but with only few short setae on those margins in female. Merus with demarcated transverse striae on dorsal surface, but with faint striae on ventral surface; relatively narrow, rounded lobe present on dorso-anterior margin distally. Carpus 1.7-1.8 times as long as maximum width, with demarcated transverse striae dorsally in male, but with only faint striae in female, those striae more distinct in dorso-anterior and dorso-posterior margins; dorso-anterior margin convex, with most swelling point posteriorly to half length, proximally with relatively short and shallow concavity. Palm with dense long setae on anterior margin but with fewer and shorter setae on posterior margin; dorsal surface strongly convex, with faint, longitudinal median ridge. Fingers distinctly crossing to each other, leaving subdistal gap when closed (that gap larger in male than female); fixed finger pointed distally, distally curved upward in male but nearly straight in female; cutting edges of both fingers denticulated, each with proximal distinct tooth (larger in male than female), nearly smooth on remaining margin. Dactylus curved to extensor side; cutting edge concave proximally, with short scattered setae in male but no setae in female.

Smaller cheliped with setation similar to that of larger cheliped. Carpus proportionally broader than that of larger cheliped, length 1.4-1.6 times as long as maximum width. Palm less convex on dorsal and ventral surfaces than that of larger cheliped, dorsal surface with distinct, longitudinal median ridge. Fingers pointed distally; cutting edges without distinct gap when closed, denticulated, bearing short setae.

Ambulatory legs (Fig. 3e, f) decreasing in size posteriorly (second pereopod largest), with plumose setae on anterior margins. Meri and carpi unarmed on entire margins, meri compressed laterally. Propodi length/ height ratios: 2.8, 2.7 (second), 2.7, 2.6 (third) for each sex and 2.8 (fourth) for both male and female; ventral surface with small corneous spines as follows: second pereopod with two proximal and three distal (one subdistal, two distoventral) spines, third with three proximal and three distal spines, fourth with two (male) or three (female) proximal and three distal spines. Dactyli each with two corneous spines on ventral margin, distal spine much larger than proximal; terminal claws bifurcated, ventral claw distinctly larger than dorsal.

Telson (Fig. 2d) composed of seven plates; proximolateral plates much smaller than others; small plate-like membrane between median and distal plates.

\section{Coloration in life}

Dorsal surfaces of carapace and chelipeds beige (Fig. 1a), with mottled brown marks as seen in tubes of host polychaete (Fig. 4c). Ambulatory legs paler beige on lateral surfaces. 


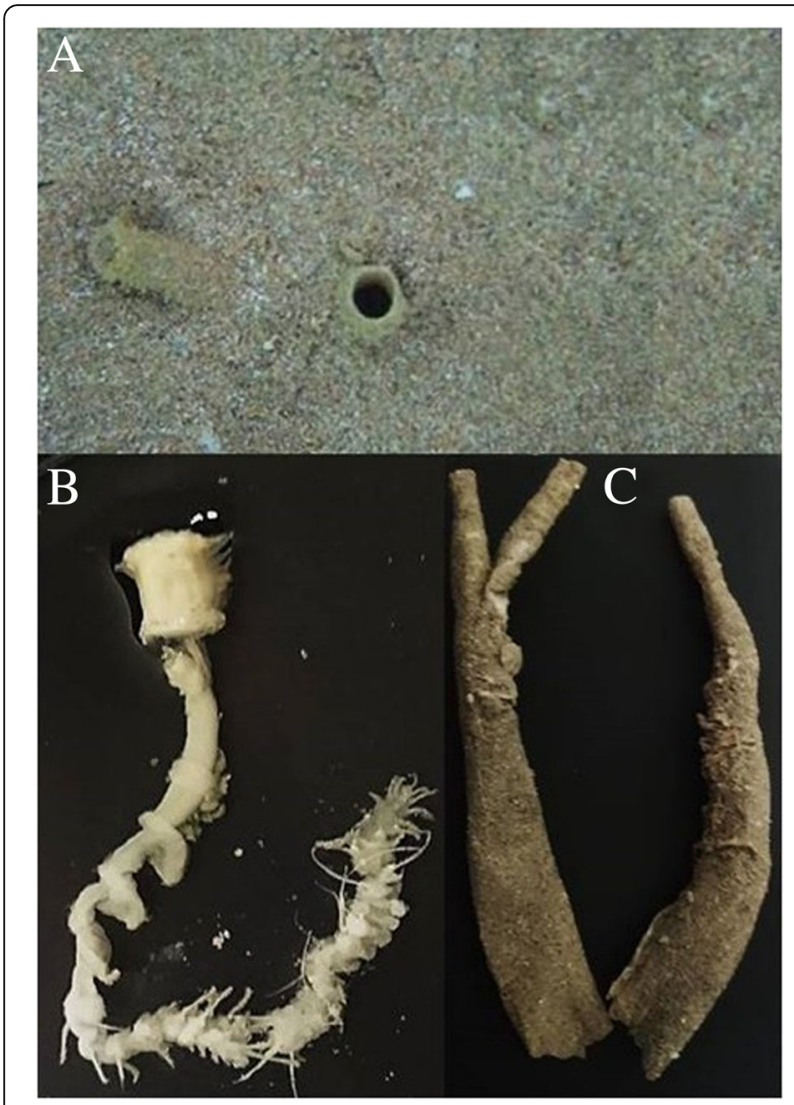

Fig. 4 Chaetopterus variopedatus (Renier, 1804), host of Polyonyx loimicola Sankolli, 1965, from Suez Gulf, Red Sea, Egypt. a openings of tube of an uncollected specimen; $\mathbf{b}$ worm; c tube

\section{Ecological notes}

The present specimens were collected from the tubes of Chaetopterus variopedatus (Renier, 1804) (Fig. 4b, c) in soft sandy substratum of shallow intertidal region (Fig. 4a). The intertidal region of the collection site in Ain-Sokhna, Egypt, exhibits a wide variation of substrates; it comprises three major habitats: rocky, sandy-rock (mixed) and sandy shores, in addition to patches of coral reef at the lower border of intertidal zone. The upper intertidal region is protected by rocks or mixed sand-rock at the shore line and is dominated by porcelain crab Petrolithes rufescens; followed by sandy bottom habitat inhabited by burrowing invertebrates including tube dwelling polychaetes. The tubes of Chaetopterus variopedatus can be easily seen in the field because they are partially projected above the ground in sandy substratum submerged in shallow intertidal region (1-2 m). Each tube is covered with sand particles; only two worms each associated with a single specimen of Polyonyx loimicola were obtained.

\section{Distribution}

So far recorded only from the eastern coast of the Arabian Sea: Mumbai (= Bombay), India, and Gwadar West Bay, Pakistan (Sankolli 1965; Tirmizi et al. 1989). Now from the Suez Gulf in Egypt, north part of the Red Sea.

\section{Remarks}

The present specimens from Egypt belong to the Polyonyx sinensis group defined by Johnson (1958) based on the following characters: the carapace lacks spines on the lateral margins, the chela with various degrees of setation on the dorso-anterior surface, and the ambulatory dactylus has the dorsal claw being much smaller than the ventral claw (see Osawa et al. 2018). The group now includes 18 Indo-West Pacific species, and among them, the present material is closely assigned to P. loimicola based on the characters used in the key to species of the P. sinensis group by Osawa et al. (2018). Nevertheless, the present specimens are different from the original description of P. loimicola by Sankolli (1965) in number of ventral spines of the ambulatory propodi, five or six spines (including two spines on the distoventral margin) in the Egyptian specimens versus three spines in the original description. At present, we prefer to identify the Egyptian specimens as P. loimicola previously known from the eastern coast of the Arabian Sea, as there is no sufficient information on the intraspecific variations.

General morphology, including the similar number of ventral spines of the ambulatory propodi, may also link to the present specimens to P. tulearis Werding, 2001 known only from Madagascar. However, P. tulearis is different from the Egyptian material and the original description of $P$. loimicola in: carapace branchial margins distinctly convergent posteriorly; median lobe of third thoracic sternite absent; and dorso-anterior margin of carpus of larger cheliped more gently and constantly convex on entire length.

Sankolli and Shenoy (1965) reported the association behaviour of $P$. loimicola in Bombay, India, and the porcellanid was always found in a heterosexual pair inside tubes of a terebellid polychaete, Loimia medusa, in sand or in a mixture of sand and mud. Such an association with terebellid is unusual for the Polyonyx sinensis group because many species of the group have been recorded from polychaetes of the family Chaetopteridae (cf. Osawa et al. 2018). The present Egyptian specimens were found in tubes of Chaetopterus variopedatus in sandy substratum.

\section{Conclusion}

Polyonyx loimicola was originally described from Bombay, India and then recorded from Pakistan. Now its distribution is expanded and recorded for the first time from the northern part of the Red Sea, 
Egyptian coast (north Suez Gulf). Moreover, intraspecific variations in the number of ambulatory propodi spines and host polychaete were observed; these requir further studies on this species from different localities including India, the Arabian Gulf and the Red Sea.

\section{Acknowledgements}

The first author (M. A. Amer) is very grateful to the management staff of Iriomote Station, Tropical Biosphere Research Center and James Davis Reimer, Faculty of Science, University of the Ryukyus, Okinawa, Japan, for hosting and providing laboratory facilities during the present study from February to August 2018

\section{Authors' contributions}

MA was involved in the field work, found the recorded species. MA and TN contributed in the morphological identification and drawings Figs. 2, 3. TN made the final arrangement of Figs. 2, 3. MO contributed in the final identification of the recorded specimens. All authors involved in the setup of the manuscript. All authors read and approved the final manuscript.

\section{Funding}

Financial support for the first author (M. A. Amer) was provided by the Egyptian government, Ministry of Higher Education (Cultural Affairs and Missions Sector, mission call 2015/2016) (grant number 331946).

\section{Availability of data and materials}

All data generated or analysed during this study are included in this published article. All voucher specimens (RCAZUE.Crus. 36401 and 36402) are deposited in the Reference Collection and Museum of Zoology, Faculty of Science, Al-Azhar University, Egypt (RCAZUE.Crus.).

\section{Ethics approval and consent to participate}

Not applicable.

\section{Consent for publication}

Not applicable.

\section{Competing interests}

The authors declare that they have no competing interests.

\section{Author details}

'Zoology Department (Marine Biology Section), Faculty of Science, Al-Azhar University, Cairo 11884, Egypt. "2riomote Station, Tropical Biosphere Research Center, University of the Ryukyus, 870 Uehara, Taketomi, Okinawa 907-1541, Japan. ${ }^{3}$ Estuary Research Center, Shimane University, 1060 Nishikawatsu-cho, Matsue, Shimane 690-8504, Japan.

Received: 26 April 2019 Accepted: 12 August 2019

Published online: 22 August 2019

\section{References}

Barnard KH. Descriptive catalogue of south African decapod Crustacea. Ann South African Museum. 1950:38:1-837.

Head SM. Introduction. In: Edwards AJ, Head SM, editors. Key environments: the Red Sea. Oxford: Pergamon Press; 1987. p. 1-21.

Johnson DS. The indo-West Pacific species of the genus Polyonyx (Crustacea, Decapoda, Porcellanidae). Ann Zool. 1958:2:95-118.

Lewinsohn C. Die Anomuren des Roten Meeres (Crustacea Decapoda: Paguridae, Galatheidea, Hippidea). Zoologische Verhandelingen. 1969;104:1-210.

Lieske E, Myers R. Korallenriff-Führer Rotes Meer. Stuttgart: Franckh-Kosmos Verlag; 2004

Nobili G. Faune carcinologique de la Mer Rouge. Decapodes et Stomatopodes. Annales des Sciences Naturelles (Zoologie) 9e série. 1906;4:1-347.

Osawa M. A new species of Polyonyx Stimpson, 1858 (Crustacea: Decapoda: Anomura: Porcellanidae) from the PANGLAO 2004 marine biodiversity project in the Philippines. Raffles Bull Zool. 2015;63:536-45.

Osawa M. A new species of the Polyonyx sinensis group (Crustacea: Decapoda: Anomura: Porcellanidae) from the Central Philippines. Zootaxa. 2018:4486(3):393-400.
Osawa M, Chan TY. Part III. Porcellanidae (Porcelain crabs). In: Chan TY, editor. Crustacean fauna of Taiwan: crab-like anomurans (Hippoidea, Lithodoidea and Porcellanidae). National Taiwan Ocean University, Keelung; 2010. p. 67-181.

Osawa M, McLaughlin PA. Annotated checklist of anomuran decapod crustaceans of the world (exclusive of the Kiwaoidea and families Chirostylidae and Galatheidae of the Galatheoidea) Part II-Porcellanidae. In: Low M E Y, Tan S H, editors. Checklists of anomuran decapod crustaceans of the world (exclusive of the Kiwaoidea and families Chirostylidae and Galatheidae of the Galatheoidea) and marine lobsters of the world. The Raffles Bull Zool. 2010:(Suppl 23):109-29.

Osawa M, Naruse T, Ng PKL. New records of species of the Polyonyx sinensis group (Crustacea: Decapoda: Anomura: Porcellanidae) from Japan, the Philippines, Singapore, and Malaysia, with descriptions of two new species. Zootaxa. 2018:4429(2):303-23.

Osawa M, Ng PK. Revision of Polyonyx pedalis Nobili, 1906 (Crustacea: Decapoda: Anomura: Porcellanidae), with descriptions of three new species. Raffles Bull Zool. 2016;(Suppl 34):499-518.

Ramadan MM. Report on a collection of Stomatopoda and Decapoda from Ghardaqa, Red Sea. Bull Faculty Sci Egypt Univ. 1936;6:1-43.

Sankolli KN. On a new species of commensal porcellanid crab, Polyonyx loimicola sp. Nov., from India (Crustacea, Anomura, Porcellanidae). J Bombay Nat Hist Soc. 1965;62:285-9.

Sankolli KN, Shenoy S. On the occurrence of the tube-worm Loimia medusa (Savigny) in Bombay waters and its commensalism with a porcellanid crab. J Bombay Nat Hist Soc. 1965:62:316-20.

Siddiqui FA, Kazmi QB. A checklist of marine anomurans (Crustacea: Decapoda) of Pakistan, northern Arabian Sea. Memoirs of Museum Victoria. 2003;60(1):87-9.

Sun Y, Qiu JW. A new species of Chaetopterus (Annelida, Chaetopteridae) from Hong Kong. Memoirs Museum Victoria. 2014;71:303-9. https://doi.org/10.241 99/j.mmv.2014.71.23

Tirmizi NM, Yaqoob M, Siddiqui FA. Marine fauna of Pakistan: 3. Porcellanid crabs (Crustacea, Anomura). Pakistan: Centre of Excellence in Marine Biology, University of Karachi; 1989.

Vine P. Red Sea invertebrates. London: IMMEL publishing; 1986.

Werding B, Hiller A. The Porcellanidae (Crustacea: Decapoda: Anomura) of the Red Sea with description of a new species of Petrolisthes. Zootaxa. 2007;1460:1-24.

Werding B, Hiller A. A new species of Polyonyx (Crustacea, Anomura, Porcellanidae) inhabiting polychaete-worm tubes (Annelida, Chaetopteridae) in the indo-West Pacific. Zookeys. 2019;818:25-34.

\section{Publisher's Note}

Springer Nature remains neutral with regard to jurisdictional claims in published maps and institutional affiliations.
Ready to submit your research? Choose BMC and benefit from:

- fast, convenient online submission

- thorough peer review by experienced researchers in your field

- rapid publication on acceptance

- support for research data, including large and complex data types

- gold Open Access which fosters wider collaboration and increased citations

- maximum visibility for your research: over $100 \mathrm{M}$ website views per year

At BMC, research is always in progress.

Learn more biomedcentral.com/submissions 